Keywords:

Forest fires

Forest protection

Fire simulation

Histórico:

Recebido 06/09/2016

Aceito 25/1 I/2016

Palavras chave: Incêndios florestais Proteção florestal Simulação do fogo

\footnotetext{
${ }^{+}$Correspondência: benjmk@hotmail.com
}

Benjamin Leonardo Alves White ${ }^{1+}$, Larissa Alves Secundo White', Genésio Tâmara Ribeiro', Rosemeri Melo Souza'

\section{FIRE BEHAVIOR PREDICTING MODELS EFFICIENCY IN BRAZILIAN COMMERCIAL EUCALYPT PLANTATIONS}

ABSTRACT: Knowing how a wildfire will behave is extremely important in order to assist in fire suppression and prevention operations. Since the 1940's mathematical models to estimate how the fire will behave have been developed worldwide, however, none of them, until now, had their efficiency tested in Brazilian commercial eucalypt plantations nor in other vegetation types in the country. This study aims to verify the accuracy of the Rothermel (1972) fire spread model, the Byram (1959) flame length model, and the fire spread and length equations derived from the McArthur (1962) control burn meters. To meet these objectives, 105 experimental laboratory fires were done and their results compared with the predicted values from the models tested. The Rothermel and Byram models predicted better than McArthur's, nevertheless, all of them underestimated the fire behavior aspects evaluated and were statistically different from the experimental data.

\section{EFICIÊNCIA DE MODELOS DE PREVISÃO DO COMPORTAMENTO DO FOGO EM PLANTAÇÕES COMERCIAIS DE EUCALIPTO NO BRASIL}

RESUMO: Saber como o fogo irá se comportar durante um incêndio florestal é de fundamental importância a fim de aprimorar e desenvolver atividades de prevenção e combate. Desde a década de 1940, modelos matemáticos para estimar o comportamento do fogo têm sido desenvolvidos no mundo inteiro, entretanto, nenhum deles, até hoje, teve sua eficiência avaliada em plantações comerciais de eucalipto no Brasil nem, tampouco, em outras vegetações encontradas no país. Este estudo tem por objetivo verificar a eficiência do modelo de propagação do fogo superficial de Rothermel (1972), do modelo de comprimento das chamas de Byram (1959) e das equações de velocidade de propagação e comprimento das chamas baseadas nas tabelas de McArthur (1962). Para tal, 105 queimas laboratoriais foram realizadas e seus resultados comparados com os valores estimados pelos modelos testados. $O$ modelo de Rothermel e de Byram previram melhor que o de McArthur, no entanto, todos eles subestimaram as variáveis do comportamento do fogo analisadas e seus valores foram significativamente diferente dos valores experimentais.
DOI:
' Federal University of Sergipe - São Cristovão, Sergipe, Brazil

CERNE | v. 22 n. 4 | p. 389-396 | 2016 


\section{INTRODUCTION}

Eucalyptus is an important industrial plantation genus planted all around the world for paper pulp, fiberboard, industrial charcoal, and fuelwood (TURNBULL, 1999). In Brazil, because of its rapid growth and good adaptation to the environmental conditions, the Eucalyptus is, by far, the most widely forest genus used for paper and cellulose production, with an estimated planted area at 5.10 million hectares (ABRAF, 20I3).

Due to the genetic improvements achieved by companies in forestry research, the trees for pulp production increase biomass very quickly, being usually harvested before reaching 7 years of age, when they attain 35 meters in height (SBS, 2009). This characteristic of the Brazilian eucalypt plantations is responsible for an accumulation of larger amounts of litter above the ground with a surface fuel arrangement, load and structure different from any other type of vegetation, including the Australian native eucalypt forests (FERNANDES et al., 20I I; BORGES et al., 20I I; WHITE et al., 20I4).

Annual economic losses caused by fires in these planted forests are quite high. In Brazil, the exact number of fires and burned area data are difficult to obtain, however Santos et al. (2006) calculated that between 1998 and 2002, 5,832 fires occurred in eucalypt plantations in the country. This amount represented $30 \%$ of all fires in all vegetation types recorded, and accounted for a burnt area of 13,562 hectares, $16 \%$ of the total area burned during this period.

The main method to prevent wildfires is through an effective program of fire prevention and suppression. This can be done more efficiently by understanding how a fire will behave. Mathematical models to describe fire behavior began to be developed in the 1940's and, according to Pastor et al. (2003), 43 different surface fire behavior models were created in 10 different countries until the year 2000. Among all different models, the Rothermel (1972) surface fire spread is the most used in the world (Pastor et al., 2003; Wells, 2008; Andrews, 2010). This model has been incorporated into many programs, such as the BehavePlus (ANDREWS et al., 2002), an update of the original BEHAVE (ANDREWS, 1983), that, according to Andrews (2010), is the leading fire behavior predicting system used in the USA.

Modelling fire behavior studies in Eucalyptus began with the work of McArthur (1962) who, using controlled burns, designed meters for determining the surface fire behavior in Australia's native forests. The meters were converted into equations by Gould (1994) and then inserted into software applications, like the CSIRO Fire Danger and Fire Spread Calculator (CSIRO, 1999), that greatly enlarged their utility. In the following decades, several researches developed new studies and models increasing the knowledge about fire behavior in eucalypt forests (Eg. PEET, 1965; MCARTHUR, 1967; BURROWS, 1994; BURROWS, 1999; ELLIS, 2000; GOULD et al., 2007; CHENEY et al., 2012; MCCAW et al., 20I2). However, the models developed by McArthur are still being used by fire management agencies in Australia and in several research activities (CRUZ et al., 20I4). Despite all these studies, a lack of comprehension of how fire behaves in eucalypt plantations outside its natural habitat remained.

Knowing that the currently existing mathematical models depend, mainly, on the characteristics of the available fuel and on atmospheric conditions (WHITE et al., 20I3), there is a need to evaluate their efficiency in different conditions from which they were developed. Therefore, this study tested, through experimental laboratorial fires, the efficiency of the Rothermel (1972) fire spread model, the Byram (1959) flame length model and the McArthur (1962) control burn meters for Brazilian commercial eucalypt plantations.

\section{MATERIAL AND METHODS}

\section{Collecting the fuel load}

The fuel collected for the laboratory burns was from the eucalypt plantations of the COPENER Florestal Ltda. company, located on the north coast of the state of Bahia, Brazil, between latitudes $11^{\circ} 15^{\prime} \mathrm{S}$ and $12^{\circ} 30^{\prime} \mathrm{S}$ and longitudes $37^{\circ} 30^{\prime} \mathrm{W}$ and $38^{\circ} 45^{\prime} \mathrm{W}$. The total area is about 100.000 hectares planted with hybrid eucalypt resulting from the cross of Eucalyptus grandis (Hill ex. Maiden) with Eucalyptus urophylla (S. T. Blake).

Forest fires occur every year at the study site and cause financial losses for the company. According to White et al. (2013a), 40I fires were detected between $0 \mathrm{I} / 2002$ and $0 \mathrm{I} / 2010$, most of them from arson. Nonpublished records of the company describe, for the same period, an average burnt area of 6 ha per fire. The largest fire damaged 48.66 ha.

\section{Laboratory burns}

The fuel load was collected from the study area and taken in nylon bags to the laboratory where 105 experimental burns were done seeking to represent different ways that a fire can behave in eucalypt stands: dry season fires, rainy season fires, low or high fuel load, with and without influence of the wind. 
The burn table of I.5 x I.5 meters was installed in a semi open area (roofless, but with 3 meter tall sidewalls) with zero degree slope at ground level. A drip torch filled with kerosene was used to ignite a $1.5 \mathrm{~m}$ width fireline located at the windward initial edge of the burn table.

The fuel arrangement in the burn table sought to represent the original fuel bed characteristics found at the study site and already described and published in a previous study (WHITE et al., 20I4).

To simulate the fire behavior using the Rothermel (1972), Byram (1959) and McArthut (1962) models, the independent variables measured in each burn were: I-h dead fuel load; I0-h dead fuel load; fuel bed depth; I-h fuel moisture; 10-h fuel moisture; and wind speed.

To determine the load and the moisture content of I-h, I0-h, the entire fuel, immediately before being burned, was separated according to the time-lag class and weighed. A small sample for each class was packaged in paper bags, weighed and dried in an oven at $100^{\circ} \mathrm{C}$ for approximately $24 \mathrm{~h}$ until they reach constant mass. Knowing the moisture content, the dry fuel load was determined.

After weighing, the fuel was homogeneously scattered onto the combustion table and the fuel bed depth was determined based on the mean of five random measurements. The wind speed was measured with a handheld anemometer (LUTRON Electronic Enterprise Model: LM-8000) positioned right before the combustion table at eye level height.

Two aspects of fire behavior (dependent variables) were analyzed: rate of spread and flame length. The rate of spread was measured with a chronometer to determine the time that the flame front passed from the first line to the end line. The flame length was determined visually with the aid of a graduated wood scale positioned right next to the combustion table and later, confirmed with photographs and videos. Some of the laboratory fires failed to propagate until the end line, therefore their given rate of spread was zero. The flame length received a zero value only when the fire extinguished before reaching the second line. More details about the burn table and experimental burns can be found in White et al. (2016).

\section{Simulating fire behavior and comparing with experimental data}

a) The Byram (1959) flame length and Rothermel (1972) rate of spread models.

At the end of each experimental burn, all the fuel and meteorological input data were used to simulate the fire rate of spread using the Rothermel (1972) model, and flame length using Byram (1959) model (Equations $I$ and 2), where: $R=$ Rate of spread $\left(\mathrm{m} \cdot \mathrm{s}^{-1}\right) ; I_{R}=$ Reaction intensity $\left(\mathrm{kW} \mathrm{m}^{-2} \cdot \mathrm{s}^{-1}\right) ; \xi=$ Propagating flux ratio; $\varphi_{\mathrm{s}}=$ Slope factor; $\varphi_{\mathrm{w}}=$ Wind factor; $\rho_{b}=$ Ovendry bulk density $\left(\mathrm{kg} \cdot \mathrm{m}^{-3}\right) ; \varepsilon=$ Effective heating number $\left(\mathrm{kJ} \cdot \mathrm{kg}^{-1}\right)$; $Q_{\text {ig }}=$ Heat of preignition $\left(\mathrm{kJ} \cdot \mathrm{kg}^{-1}\right) ; F_{L}=$ Flame length $(\mathrm{m})$; $I_{B}=$ Byram's fireline intensity $\left(\mathrm{kW} \mathrm{m}^{-1} \cdot \mathrm{s}^{-1}\right)$.

All the simulations where done using the BehavePlus Fire Modeling System version 5.0.5 (ANDREWS, 2009), with custom fuel models. The values needed to perform the simulations for the I-h surface-area-to-volume ratio (SAV), dead fuel moisture of extinction and dead fuel heat content, were based on a review of studies done in eucalypts plantations (CHANDLER et al., 1983; MOORE, 1986; CRUZ, 2005; SOARES; BATISTA, 2007; FERNANDES et al. 20I I), and set as $4,200 \mathrm{~m}^{2} \cdot \mathrm{m}^{-3}, 30 \%$, and $21,000 \mathrm{~kJ} \cdot \mathrm{kg}^{-1}$, respectively.

$\mathrm{R}=\frac{\mathrm{I}_{\mathrm{R}} \times \xi \times\left(1+\varphi_{\mathrm{s}}+\varphi_{\mathrm{W}}\right)}{\rho_{\mathrm{b}} \times \varepsilon \times \mathrm{Q}_{\mathrm{ig}}}$

$F_{L}=0.0775 \mathrm{I}_{B} 0.46$

b) The McArthur (1962) model

To simulate the fire rate of spread and flame length using the McArthur (1962) model for controlled burns in eucalypt forests, it was initially necessary to determine the available fuel load. The McArthur model calculates this by multiplying the total dry fuel load by the fuel reduction factor (defined according to the amount of rainfall and the number of days since the last rain). In this study, the available fuel load was defined by the total fuel load minus the unburned load weight at the end of each experiment.

The equations derived from the McArthur (1962) meters and described by Gould (1994), were used to determine the rate of spread and the flame height (Equations 3 and 4). The flame height was converted to flame length using basic trigonometry (Equation 5), where: $R=$ Rate of spread $\left(\mathrm{m} \mathrm{min}^{-1}\right) ; U_{1.5}=$ Wind speed at I.5m $\left(\mathrm{km} \mathrm{h}^{-1}\right) ; M_{f}=$ Fuel moisture content (\%); $\mathrm{FI}_{h}=$ Flame height $(\mathrm{m}) ; \mathrm{W}=$ Available fuel load $\left(\mathrm{t} \mathrm{ha}^{-1}\right) ; \mathrm{FI}=$ Flame length $(\mathrm{m}) ; \varphi=$ Flame angle.

$$
\begin{aligned}
& \mathrm{R}=0.22 * \mathrm{~W} * \exp \left(0.158 \mathrm{U}_{1.5}-0.227 \mathrm{M}_{\mathrm{f}}\right) \\
& \mathrm{FI} \mathrm{I}_{\mathrm{h}}=0.163 * \mathrm{~W} 0.862 * \mathrm{R} 0.890 \\
& \mathrm{FI}=\frac{\mathrm{FI}_{\mathrm{h}}}{\operatorname{Sin}(\varphi)}
\end{aligned}
$$


All the simulated values were compared with the experimental data through the Wilcoxon Signed-Ranks test, a nonparametric test designed to evaluate the difference between two treatments where the samples are correlated. To verify the performance of each model in predicting the fire behavior, the following statistical measures of agreement between predicted and observed values were assessed: the Pearson correlation ( $r$ ); the coefficient $p$-value; the root mean square error (RMSE); the mean absolute percent error (MAPE); and the mean absolute error (MAE). Predicted and observed data were also plotted as scattergrams and compared with the line of exact agreement.

\section{RESULTS}

\section{Laboratory burns}

Overall, most of the experimental burns propagated slowly and with short flame due to the high moisture content of the fuel load that presented a mean value of approximately $17 \%$. According to the classification of Botelho and Ventura (1990), the rate of spread was in most cases "slow", with a speed less than $1.98 \mathrm{~m} \cdot \mathrm{min}^{-1}$. In only three experiments the speed reached the "medium" classification (I.98 - 9.96 $\left.\mathrm{m} \cdot \mathrm{min}^{-1}\right)$. The flame length, in most cases, was "short" $(<0.6 \mathrm{~m})$ according to Roussopoulos and Johnson (1975) classification. The maximum length was $1.2 \mathrm{~m}$. Some of the laboratory fires failed to propagate therefore their given rate of spread and flame length was zero (Table I).

TABLE I Mean, standard deviation, maximum and minimum values for all input and output parameters used to estimate the fire behavior and compare with experimental data.

\begin{tabular}{|c|c|c|c|}
\hline Input Parameter & $\begin{array}{c}\text { Mean } \\
\text { (Standard Deviation) }\end{array}$ & Maximum & Minimum \\
\hline $\begin{array}{l}\text { I-h dead dry fuel load } \\
\left(\mathrm{t} \cdot \mathrm{ha}^{-1}\right)\end{array}$ & $8.21( \pm 2.99)$ & 19.37 & 1.94 \\
\hline $\begin{array}{c}\text { 10-h dead dry fuel load } \\
\left(\mathrm{t} \cdot \mathrm{ha}^{-1}\right)\end{array}$ & $2.76( \pm 3.84)$ & 22.72 & 0 \\
\hline $\begin{array}{c}\text { Fuel bed depth } \\
\text { (m) }\end{array}$ & $0.037( \pm 0.021)$ & 0.118 & 0.008 \\
\hline $\begin{array}{l}\text { I-h moisture content } \\
(\%)\end{array}$ & $17.78( \pm 7.12)$ & 38.5 & 7.7 \\
\hline $\begin{array}{c}\text { I0-h moisture content } \\
(\%)\end{array}$ & $16.64( \pm 4.69)$ & 41.52 & 8.4 \\
\hline $\begin{array}{l}\text { Wind speed } \\
\qquad\left(\mathrm{km} \cdot \mathrm{h}^{-1}\right)\end{array}$ & $3.66( \pm 3.7)$ & 15 & 0 \\
\hline Output Parameter & $\begin{array}{c}\text { Mean } \\
\text { (Standard Deviation) }\end{array}$ & Maximum & Minimum \\
\hline $\begin{array}{l}\text { Rate of spread } \\
\qquad\left(\mathrm{m} \cdot \mathrm{min}^{-1}\right)\end{array}$ & $0.46( \pm 0.59)$ & 3.13 & 0 \\
\hline Flame length (m) & $0.45( \pm 0.29)$ & 1.2 & 0 \\
\hline
\end{tabular}

Although the meteorological parameters in the laboratory were similar to those described in the field (WHITE et al., 20I3a; WHITE et al., 2014), extreme dryness and high wind speed conditions were not analyzed. More on the characteristics of all parameters measured during the 105 laboratory burns are available at White et al. (2016).

\section{Simulating the fire behavior with Rothermel and Byram models and comparing with experimental data}

The experimental rate of spread was, on average, 2.85 times greater than predicted by the Rothermel (1972) fire spread model. The Wilcoxon test confirmed statistical difference between both data $(Z=-7.95 ; p<0.01)$. The flame length during the experiments was also, on the average, 2.39 times larger than predicted by the Byram (1959) model. Similarly, these results were statistically different through Wilcoxon test $(Z=-8.35 ; p<0.0$ I $)$.

\section{Simulating the fire behavior with the McArthur model and comparing with experimental data}

The experimental rate of spread was, on average, 2.77 times greater than predicted by the McArthur (1962) control burn model. The Wilcoxon test proved that both data had a significant statistical difference $(Z=-6.44 ; p$ $<0.01$ ). Regarding the flame length, the experimental data was, on average, I.47 times larger than simulated. The Wilcoxon test again attested statistical difference between both data $(Z=-5.14 ; p<0.01)$. The line of exact agreement is shown superimposed over the scatter plot of predicted and observed values for the

TABLE 2 Mean, mean difference, root mean square error (RMSE), mean absolute error (MAE), mean absolute percent error (MAPE), Pearson correlation ( $r$ ) and significance values $(\mathrm{p})$ for the predicted and observed rate of spread and flame length.

\begin{tabular}{|c|c|c|c|c|c|c|c|}
\hline & Mean & $\begin{array}{c}\text { Mean } \\
\text { Difference }\end{array}$ & RMSE & MAE & $\begin{array}{l}\text { MAPE } \\
(\%)\end{array}$ & $r$ & $\mathrm{P}$ \\
\hline $\begin{array}{c}\text { R Observed } \\
\left(\mathrm{m} \cdot \mathrm{min}^{-1}\right) \\
\text { R Rothermel } \\
\left(\mathrm{m} \cdot \mathrm{min}^{-1}\right)\end{array}$ & $\begin{array}{l}0.459 \\
0.161\end{array}$ & 0.298 & 0.527 & 0.306 & 54.291 & 0.726 & 0.001 \\
\hline $\begin{array}{l}\text { R Observed } \\
\left(\mathrm{m} \cdot \mathrm{min}^{-1}\right) \\
\text { R McArthur } \\
\left(\mathrm{m} \cdot \mathrm{min}^{-1}\right)\end{array}$ & $\begin{array}{l}0.459 \\
0.166\end{array}$ & 0.293 & 0.588 & 0.347 & 58.809 & 0.505 & 0.001 \\
\hline $\begin{array}{c}\text { FI Observed } \\
(\mathrm{m}) \\
\text { FI Byram } \\
(\mathrm{m})\end{array}$ & $\begin{array}{l}0.454 \\
0.190\end{array}$ & 0.264 & 0.330 & 0.269 & 58.434 & 0.637 & 0.001 \\
\hline $\begin{array}{l}\text { FI Observed } \\
(\mathrm{m}) \\
\text { FI McArthur } \\
(\mathrm{m})\end{array}$ & 0.454 & 0.149 & 0.430 & 0.322 & 71.022 & 0.578 & 0.001 \\
\hline
\end{tabular}



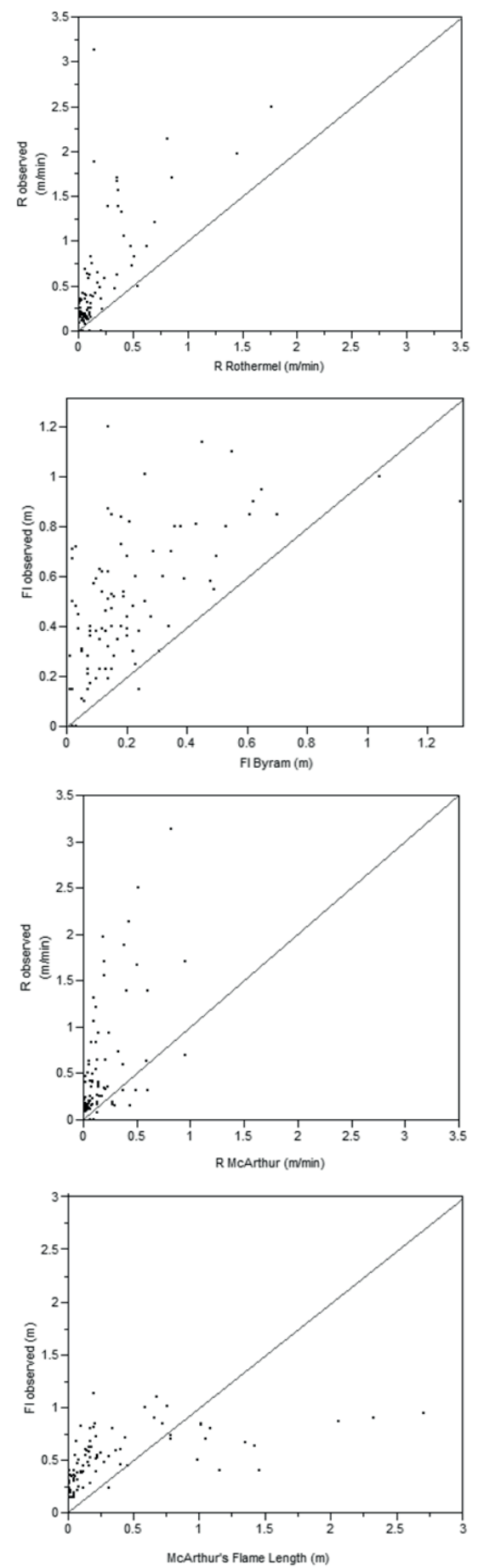

FIGURE I Observed rate of spread versus predicted with the Rothermel (1972) and the McArthur (1962) models; observed flame length versus predicted with Byram (1959) and McArthur (1962) models. The line indicates the exact agreement.

rate of spread and flame length (Figure I). Values for mean, mean difference, root mean square error, mean absolute error and correlation test between simulated and observed values are presented in Table 2 .
Although the rate of spread and flame length simulated with the McArthur model presented a mean value closer to the observed mean, all the statistical parameters indicated that the Rothermel and Byram models were better in predicting these fire behavior parameters.

\section{DISCUSSION}

The simulations data using Rothermel (1972), Byram (1959) and McArthur (1962) models exhibited significant differences when compared to the experimental data. All the models under-predicted the rate of spread and flame length with a mean absolute percent error (MAPE) between 54-7I\%.

Cruz and Fernandes (2008) using the Rothermel (1972) fire spread model to assess the surface fire rate of spread in conifer forest in northern Portugal, found that $65 \%$ of the experimental fires were under-predicted while $35 \%$ over-predicted. According the same authors, the MAPE was $42 \%$. Under-prediction bias by the Rothermel (1972) surface fire spread model was already reported by several other authors such as McCaw (1995) in Australian shrubland; Grabner et al. (1999) in oak savannas in the USA; Stephens et al. (2008) and Weise et al. (2016) in chaparral fuel beds of California; and others. Cruz and Alexander (2013) in a review over 49 different publications that evaluated the efficiency of several different rate of spread predicting models (including the Rothermel model), determined that only $3 \%$ of the predictions ( 35 out of 1278) were considered to be exact. According the same authors, under-prediction bias was prevalent in $75 \%$ of the models and more than half of them had mean absolute percent error between $5 \mathrm{I}$ and $75 \%$. Another review done by White et al. (2013b) also affirms that most of the studies using the Rothermel (1972) model under-predicted the fire rate of spread.

The Byram (1959) flame length model is calculated from fireline intensity, which is a function of rate of spread and heat per unit area. Fernandes (2009) in conifer forest litter in Sevivas, Portugal, concluded that the Byram (1959) model under-predicted observed experimental flame length. Similar results were found by Stephens et al. (2008) when comparing the predicted Byram's flame length with observed values from Chaparral Prescribed Fires in Northern California. The Byram's fireline intensity is useful to quantify certain flame characteristics but one should not necessarily always expect good agreement between observed flame lengths and predictions (CHENEY, 1990; ALEXANDER; CRUZ, 20I2). White et al. (2013b) affirms that just like the Rothermel (1972), the Byram's (1959) model under-predicted the flame length in most of the studies reviewed. 
Studies that assessed the efficiency of the McArthur (1962) control burn model were done mostly in Australia. Davis (1976) compared control burn model predictions with observed rates of spread in dry sclerophyll forest in the Black Mountain Reserve, Australia, and obtained a MAPE of $38 \%$ and a $0.12 \mathrm{~m} / \mathrm{min}$ mean under-prediction bias. Tolhurst et al. (1992), doing prescribed fires in Australian eucalypt forest found that $59 \%$ of the fires rate of spread were under-predicted with a MAPE of $48 \%$. Gould (1994) asserts that the model under-predicted the rate of spread in regrowth Eucalyptus sieberi forests in $89 \%$ of the cases. The McArthur (1967) models for wildfires in dry eucalypt forest also under-estimated about 2 or 3 times the fire rate of spread in natural eucalyptus forests in Australia during the dry summer (GOULD et al., 2007; CRUZ et al., 20I4). McCaw et al. (2008) described an under-prediction bias for fire rate of spread and other fire behavior characteristics including fire intensity, flame dimensions and spotting potential by the McArthur (1973) Mark V model in Australian Eucalyptus marginata forests.

Model predictions are quite often quoted to a decimal place, implying considerable precision in the outcome (ALEXANDER; CRUZ, 20I2). Nevertheless, it is important to consider that fire combustion is a very dynamic event due to the heterogeneity in fuelbed structure and changes in the wind. Therefore, it is practically impossible for a model to be correct $100 \%$ of the time. Unfortunately, there is no generally agree upon standard that currently exists within the wildland fire community in regard to what constitutes as an acceptable error in a prediction from a fire behavior model. However, Cruz and Alexander (2013) established that a $\pm 35 \%$ mean absolute percent error should constitute a reasonable and conservative standard for fire spread rate model performance. Since all the simulations in this study presented MAPE values above $35 \%$, there is a need to evaluate other models or build new ones in order to better predict fire behavior in Brazilian commercial eucalypt plantations. An efficient fire behavior predicting model is the key for effective management action before and during a fire (CRUZ et al., 2014).

\section{CONCLUSION}

The Byram (1959), McArthur (1962) and Rothermel (1972) fire behavior predicting models significantly underestimated the fire rate of spread and flame length when compared with laboratory burns data with a high mean absolute percent error between 54-71\%. Overall, the Rothermel (1972) and Byram (1959) models predicted better than the McArthur (1962) model.
The results obtained in this study justify the demand for new fire behavior models capable of precisely predicting fire behavior in Brazilian commercial eucalypt plantation. These new models can assist in the development of fire prevention and suppression strategies, therefore reducing the negative impacts caused by wildfires.

\section{ACKNOWLEDGMENT}

FAPITEC/SE scholarship fund awarded to the first author; Professor Theodore James White; Dr. Paulo Fernandes; and the anonymous revisers.

\section{REFERENCES}

ABRAF - Associação Brasileira de Produtores de Floresta Plantada. Anuário estatístico ABRAF 2013 ano base 20 I 2. Brasília: ABRAF, 20I3. I42 p.

ALEXANDER, M. E.; CRUZ, M. G. Interdependencies between flame length and fireline intensity in predicting crown fire initiation and crown scorch height. International Journal of Wildland Fire, v. 2I, n. 2, p. 95-II3, 2012.

ANDREWS, P. L. A system for predicting the behaviour of forest and range fires. In: SCS CONFERENCE OF COMPUTER SIMULATION IN EMERGENCY PLANNING, 1983. Proceedings..., p. 75-78, San Diego: 1983.

ANDREWS, P. L. BehavePlus fire modeling system, version 5.0: Variables. USDA Forest Service, Rocky Mountain Research Station, General Technical Report RMRS-GTR2I3WWW Revised. Ogden, UT, 2009.

ANDREWS, P. L. Do you Behave? - Application of the BehavePlus Fire Modeling System. In: 3RD FIRE BEHAVIOR AND FUELS CONFERENCE, 2010. Proceedings..., 17 p., Washington: 2010.

ANDREWS, P. L.; BEVINS, C.; CARLTON, D. BEHAVEPIus fire modeling system. Version I.0: user's guide. USDA, Forest Service, Rocky Mountain Research Station, Systems for Environmental Management. Fort Collins, CO, 2002.

BORGES, T. S.; FIEDLER, N. C.; DOS SANTOS, A. R.; LOUREIRO, E. B.; MAFIA, R. G. Desempenho de alguns índices de risco de incêndios em plantios de eucalipto no norte do Espírito Santo. Floresta e Ambiente, v. 18, n. I, p. I53-159, 2011 .

BOTELHO, H. S.; VENTURA, J. Modelos de comportamento do fogo. In: REGO, F. C.; BOTELHO, H. S. (Eds.). A técnica do fogo controlado. Universidade de Trás-osMontes e Alto Douro: Vila Real, p. 49-55, 1990.

BURROWS, N. D. Experimental development of a fire management model for jarrah (Eucalyptus marginata) forest. PhD Thesis, Department of Forestry, Australian National University, Canberra, Australia, 1994. 
BURROWS, N. D. Fire behaviour in jarrah forest fuels. Part 2. Field experiements. CALMScience, v. 3, p. 57-84, 1999.

BYRAM, G. M. Combustion of Forest Fuels. In: DAVIS, K. P. (Ed.). Forest Fire: Control and Use. New York: McGrawHill, p. 6I-89, 1959.

CHANDLER, D.; CHENEY N. P.; TRABAUD, L. Fire in Forestry, vol. I, Forest Fire Behavior and Effects. New York: John Wiley \& Sons, 1983.

CHENEY, N. P. Quantifying bushfires. Mathematical and Computer Modelling, v. 13, n. 12, p. 9-15, 1990.

CHENEY, N. P.; GOULD, J. S.; MCCAW, W. L.; ANDERSON, W. R. Predicting fire behaviour in dry eucalypt forests in southern Australia. Forest Ecology and Management, v. 280, p. |20-|3|, 2012.

CRUZ, M. G. Guia fotográfico para identificação de combustíveis florestais - Região Centro. Coimbra: ADAI, 2005. 38p.

CRUZ, M. G.; ALEXANDER, M. E. Uncertainty associated with model predictions of surface and crown fire rates of spread. Environmental Modelling \& Software, v. 47, p. 16-28, 2013.

CRUZ, M. G.; FERNANDES, P. M. Development of fuel models for fire behaviour prediction in maritime pine (Pinus pinaster Ait.) stands. International Journal of Wildland Fire, v. 17, n. 2, p. 194-204, 2008.

CRUZ, M. G.; SULLIVAN, A. L.; LEONARD, R.; MALKIN, S.; MATTHEWS, S.; GOULD, J. S.; ALEXANDER, M. E. Fire behaviour knowledge in Australia: a synthesis of disciplinary and stakeholder knowledge on fire spread prediction capability and application. Melbourne, Victoria: Bushfire Cooperative Research Centre, 2014.

CSIRO BUSHFIRE BEHAVIOURAND MANAGEMENT GROUP. The CSIRO Fire Danger and Fire Spread Calculator. 1999. Online, available at: http://www.csiro.au/Outcomes/ Safeguarding-Australia/Forest-Fire-Danger-Meter.aspx

DE MAR, P.; ADSHEAD, D. Blue gum plantation fuel and fire behavior guide. GHD publication for the Australian Government Department of Agriculture, Fisheries and Forestry. Canberra, ACT, 20II.

DEEMING, J. E.; BURGAN, R. E.; COHEN, J. D. The National Fire-danger Rating System- 1 978. USDA Forest Service, Intermountain Forest and Range Experiment Station General: Ogden, UT, 1977. 63p. (Technical Report INT-39).

ELLIS, P. F. The aerodynamic and combustion characteristics of eucalypt bark: a firebrand study. PhD Thesis, Department forestry, Australian National University, Camberra, Australia, 2000.
FERNANDES, P. A. M. Examining fuel treatment longevity through experimental and simulated surface fire behaviour: a maritime pine case study. Canadian Journal Forest Research, v. 39, p. 2529-2535, 2009.

FERNANDES, P. A. M.; LOUREIRO, C.; PALHEIRO, P.; VALEGONÇALVES, H.; FERNANDES, M. M.; CRUZ, M. G. Fuels and fire hazard in blue gum (Eucalyptus globulus) stands in Portugal. Boletín del CIDEU, v. I0, p. 53-6I, 201 I.

GOULD, J. S. Evaluation of McArthur's control burning guild in regrowth Eucalyptus sieberi forest. Australian Forestry, v. 57, p. 86-93, 1994.

GOULD, J. S.; MCCAW, W. L.; CHENEY, N. P.; ELLIS, P. F.; KNIGHT, I. K.; SULLIVAN, A. L. Project Vesta - Fire in Dry Eucalypt Forest: Fuel Structure, Fuel Dynamics and Fire Behaviour. Canberra: Ensis, 2007, 218p.

HIGA, R. C. V.; MORA, A. L.; HIGA, A. R. Plantio de Eucalipto na Pequena Propriedade Rura. Colombo: Embrapa Florestas, 2000, 3 Ip. (Documento 54).

MATTHEWS, S. Effect of drying temperature on fuel moisture content measurements. International Journal of Wildland Fire, v. 19, p. 800-802, 2010.

MCARTHUR, A. G. Control burning in eucalypt forest. Canberra: Commonwealth of Australia Forestry and Timber Bureau, 1962. (Leaflet No. 80).

MCARTHUR, A. G. Fire behaviour in eucalypt forests. Canberra: Commonwealth of Australia Forestry and Timber Bureau, 1967. (Leaflet No. 107).

MCARTHUR, A.G. Forest Fire Danger Meter Mark V. Canberra: Commonwealth of Australia Forestry and Timber Bureau, 1973.

MCCAW, W. L.; BURROWS, N. D.; FRIEND, G. R.; GILL, A. M. Predicting fire spread in Western Australian mallee-heath. CALMScience Supplement, v. 4, p. 35-42, 1995.

MCCAW, W. L.; GOULD, J. S.; CHENEY, N. P. Existing fire behaviour models underpredict the rate of spread of summer fires in open jarrah (Eucalyptus marginata) forest. Australian Forestry, v. 7I, p. 16-26, 2008.

MCCAW, W. L.; GOULD, J. S.; CHENEY, N. P.; ELLIS, R. M. F; ANDERSON, W. R. Changes in behaviour of fire in dry eucalypt forest as fuel increases with age. Forest Ecology and Management, v. 27I, p. I70-I8I, 2012.

MOORE, P. F. Comparison of the Forest Fire Danger Meter Mk.5 and the BEHAVE fire behavior prediction system in a dry eucalypt forest. Thesis, Dissertation, University of Montana, 1986. (Professional Papers, Paper I87I)

PASTOR, E.; ZARATE, L.; PLANAS, E.; ARNALDOS, J. Mathematical models and calculation systems for the study of wildland fire behaviour. Progress in Energy and Combustion Science, v. 29, p. I39-I53, 2003. 
PEET, G. B. A fire danger rating and controlled burning guide for Northern Jarrah Forest of Western Australia. Forests Department Western Australia Bulletin No 74, 1965.

ROTHERMEL, R. C. A mathematical model for predicting fire spread in wildland fuels. USDA Forest Service, Intermountain Forest and Range Experiment Station. Ogden, UT, 1972, 40p. (Research Paper INT-I I 5).

SANTOS, J. F;; SOARES, R. V.; BATISTA, A. C. Perfil dos Incêndios florestais no Brasil em áreas protegidas no período de 1998 a 2002. Revista Floresta, v. 36, p. 93-100, 2006.

SOARES, R. V.; BATISTA, A. C. Incêndios Florestais: controle, efeitos e uso do fogo. Curitiba: UFPR, 2007, 264p.

STEPHENS, S. L.; WEISE, D. R.; FRY, D. L.; KEIFFER, R. J.; DAWSON, J.; KOO, E.; POTTS, J.; PAGNI, P. J. Measuring the rate of spread of chaparral prescribed fires in Northern California. Fire Ecology, v. 4, n. I, p. 74-86, 2008.

TOLHURST, K. G.; FLINN, D. W.; LOYN, R. H.; WILSON, A. A. G.; FOLETTA, I. Ecological effects of fuel reduction burning in a dry sclerophyll forest: a summary of principal research findings and their management implications. Melbourne: Department of Conservation and Environment, 1992.
TURNBULL, J. W. Eucalypt plantations. New Forests, v. I7, p. 37-52, 1999.

WEISE, D. R.; KOO, E.; ZHOU, X.; MAHALINGAM, S.; MORANDINI, F; BALBI, J. H. Fire spread in chaparral-a comparison of laboratory data and model predictions in burning live fuels. International Journal of Wildland Fire, v. 25, n. 9, p. 980-994, 2016.

WELLS, G. The Rothermel Fire-Spread Model: Still Running Like a Champ. Fire Science Digest, v. 2, p. I-I 2, 2008.

WHITE, B. L. A.; WHITE, L. A. S.; RIBEIRO, G. T.; FERNANDES, P. A. M. Development of a fire danger index for eucalypt plantations in the northern coast of Bahia, Brazil. Revista Floresta, v. 43, p. 601-610, 2013a.

WHITE, B. L. A.; RIBEIRO, G. T.; SOUZA, R. M. O uso do BehavePlus como ferramenta para modelagem do comportamento e efeito do fogo. Pesquisa Florestal Brasileira, v. 33, p. 73-84, 20I3b.

WHITE, B. L. A.; RIBEIRO, G. T.; SOUZA, R. M. Caracterização do material combustível e simulação do comportamento do fogo em eucaliptais no litoral norte da Bahia, Brasil. Revista Floresta, v. 44, p. 33-42, 2014.

WHITE, B. L. A.; WHITE, L. A. S.; RIBEIRO, G. T.; SOUZA, R. M. Empirical models for describing fire behavior in Brazilian commercial eucalypt plantations. CERNE, v. 22, n. 4, p. 397-406, 2016. 